\title{
A Multiplex PCR for the Detection of Phytophthora nicotianae and P. cactorum, and a Survey of Their Occurrence in Strawberry Production Areas of Japan
}

Mingzhu Li, The United Graduate School of Agriculture Science, Takahiro Asano, River Basin Research Center, Haruhisa Suga, Life Science Research Center, and Koji Kageyama, River Basin Research Center, Gifu University, Gifu 501-1193, Japan

\begin{abstract}
Li, M., Asano, T., Suga, H., and Kageyama, K. 2011. A multiplex PCR for the detection of Phytophthora nicotianae and P. cactorum, and a survey of their occurrence in strawberry production areas of Japan. Plant Dis. 95:1270-1278.

We aimed to simultaneously detect two pathogens causing strawberry diseases, Phytophthora nicotianae and P. cactorum, by multiplex polymerase chain reaction (PCR), and to survey their occurrence in the main strawberry production areas of Japan. Due to the need to combine different primer pairs for multiplex PCR and the low specificity of published specific primers for $P$. nicotianae and $P$. cactorum, new species-specific primers for $P$. nicotianae and $P$. cactorum were designed based on the internal transcribed spacer regions of ribosomal DNA and the ras-related protein gene $Y p t 1$, respectively. Specificity of the designed primers was demonstrated using 68 isolates, including Phytophthora spp., Pythium spp., and other soilborne pathogens. Multiplex

PCR discriminated between $P$. nicotianae and $P$. cactorum in DNA mixtures of mycelia of the two species. Moreover, both species were detected in artificially and naturally infested soils, indicating that these markers can be used in diagnosis of strawberry diseases. For investigation of the geographic distribution of the two pathogens in Japan, soil samples were collected in 89 strawberry fields from eight prefectures (Gifu, Saga, Nara, Tochigi, Chiba, Shizuoka, Yamanashi, and Hokkaido) of Japan. The method that was developed was successfully applied to survey $P$. nicotianae and $P$. cactorum, and distribution of the two pathogens in strawberry plantings in Japan was determined.
\end{abstract}

In Japan, new cultivars of strawberry have been bred in order to satisfy consumer tastes. However, most of the cultivars are highly susceptible to diseases. The most serious strawberry diseases, such as anthracnose, Phytophthora rot and Fusarium wilt, were responsible for losses of almost $\$ 50$ million over the last 4 years in Japan.

In 1978, an outbreak of Phytophthora rot of strawberry was recorded in Shizuoka Prefecture, Japan $(26,27)$. The species commonly causing Phytophthora rot of strawberry are Phytophthora nicotianae and $P$. cactorum $(12,26)$. Although these pathogens are not widespread in Japan, the crown rot and wilt symptoms are similar to those caused by the anthracnose pathogen Colletotrichum gloeosporioides. Consequently, incorrect diagnoses may occur, which complicate pathogen control and transplant storage. Moreover, no investigations into their distribution across Japan have been conducted. Therefore, it is important to develop a simple and fast method to detect and distinguish these pathogens.

It is often difficult to control diseases caused by Phytophthora spp. because the pathogens release resistant perennating oospores or chlamydospores into the soil. Early detection and diagnosis of the pathogen in plants, soil, or water is essential for development of an effective disease control strategy. Traditional detection methods such as baiting and soil dilution plating methods are difficult and time consuming, and require extensive experience. With the development of DNA-based techniques, polymerase chain reaction (PCR) became a primary method of plant pathogen identification and detection $(7,8,19)$. Diagnostic PCR methods and primers have been devised for Phytophthora spp., including $P$. nicotianae $(9,16,18,21)$ and $P$. cactorum $(2,4,17,23)$. However, because some closely related Phytophthora spp. were not distinguished in previous research, it remains difficult to establish that those primers actually are specific. Furthermore, there is no report on simultaneous detection of the two species.

Corresponding author: M. Li, E-mail: mingzhu_li@mail.green.gifu-u.ac.jp

Accepted for publication 31 May 2011.

doi:10.1094/PDIS-01-11-0076

(C) 2011 The American Phytopathological Society
The internal transcribed spacer (ITS) regions of nuclear-encoded ribosomal DNA (rDNA) genes are widely used to identify and detect Phytophthora spp. (6). However, they are not always sufficiently diverse to allow separation of closely related taxa $(16,22,24)$. The elicitin gene parA 1 and the putative storage protein gene family, $L p v$, proved to be suitable targets for the specific detection of $P$. nicotianae and $P$. cinnamomi, respectively $(14,15)$. Unfortunately, these genes do not contain introns and, therefore, are unlikely to be sufficiently diverse to enable the distinction of a broad range of species (22). The ras-related protein gene Ypt 1 (5) appears to be a more promising target because it contains sufficient variation to allow for the development of molecular markers for almost all Phytophthora spp. (22). However, available sequence data are limited.

In this study, we developed a multiplex PCR assay for the simultaneous detection of $P$. nicotianae and $P$. cactorum that infect strawberry plants in Japan. We designed primers specific for $P$. nicotianae and $P$. cactorum based on ITS regions and the Ypt 1 gene, respectively. We applied the novel multiplex PCR technique to samples from infested fields, which enabled us to investigate the distribution of the two pathogens in the main strawberry cultivation regions of Japan.

\section{Materials and Methods}

Species and strain maintenance. In all, 31 Phytophthora spp., 11 additional oomycetes (genera Pythium and Saprolegnia), and 5 other soilborne pathogens, including Plasmodiophora, Pyrenochaeta, Rhizoctonia, and Verticillium spp., were used (Table 1). The P. nicotianae isolates with different hosts were provided by Centraalbureau für Schimmelcultures and the local agriculture research centers of Japan. The $P$. cactorum isolates from strawberry were collected from different prefectures of Japan. Other Phytophthora spp., Pythium spp., and pathogens were collected from several scientific resource institutions and Gifu University Cultures Collection. The Phytophthora spp. and all culturable isolates were maintained on corn meal agar or potato dextrose agar at $20^{\circ} \mathrm{C}$ in the dark.

Collection of soil samples. In total, 89 soil samples from 89 sampling strawberry fields in eight strawberry production areas (Gifu, Nara, Chiba, Saga, Shizuoka, Tochigi, Yamanashi, and 
Table 1. Specificity of the designed primer pairs to Phytophthora nicotianae and $P$. cactorum using simplex polymerase chain reaction ${ }^{\mathrm{a}}$

\begin{tabular}{|c|c|c|c|c|c|}
\hline Species & Isolate $^{b}$ & Host & Location & $\begin{array}{l}\text { ITS region, } \\
\text { Nic-F1/R1c }\end{array}$ & $\begin{array}{c}\text { Ypt1 gene, } \\
\text { Cac-F3/ R3-2d }\end{array}$ \\
\hline \multirow[t]{13}{*}{ P. nicotianae } & CH02FPK3 & Strawberry & Chiba, Japan & + & - \\
\hline & GF465 & Strawberry & Gifu, Japan & + & - \\
\hline & GF101 & Karankoe & Gifu, Japan & + & - \\
\hline & CBS305.29 & Tobacco & Taiwan & + & - \\
\hline & CBS101655 & Alstromerea & Netherland & + & - \\
\hline & $\mathrm{C} 08$ & Ardisia crispa & Chiba, Japan & + & - \\
\hline & $\mathrm{C} 15$ & Echium wildpretii & Chiba, Japan & + & - \\
\hline & $\mathrm{C} 23$ & Abutilon sp. & Chiba, Japan & + & - \\
\hline & $\mathrm{C} 26$ & Lavandula angustifokia & Chiba, Japan & + & - \\
\hline & C58 & Gerbera & Chiba, Japan & + & - \\
\hline & $\mathrm{C} 83$ & Strelitzia reginae & Okinawa, Japan & + & - \\
\hline & F03 & Nerine sarniensis & Fukuoka, Japan & + & - \\
\hline & Ch03OKTYPE3 & Strawberry & Okayama, Japan & + & - \\
\hline \multirow{9}{*}{ P. cactorum } & GF654 & Strawberry & Gifu, Japan & - & + \\
\hline & CH03 OKTYPE1 & Strawberry & Okayama, Japan & - & + \\
\hline & CH99PFT4 & Strawberry & Chiba, Japan & - & + \\
\hline & CH01FPA1 & Strawberry & Chiba, Japan & - & + \\
\hline & CH07INBA1-2 & Strawberry & Chiba, Japan & - & + \\
\hline & CH99FV2 & Strawberry & Miyagi, Japan & - & + \\
\hline & CH08N4-2 & Strawberry & Shimane, Japan & - & + \\
\hline & CH02PMN001 & Strawberry & Tokushima, Japan & - & + \\
\hline & EID2 & Strawberry & Chiba, Japan & - & + \\
\hline P. cajani & WPC3105 & Cajanus cajan & India & - & - \\
\hline P. cambivora & WPC6358 & Almond & Australia & - & - \\
\hline \multirow{2}{*}{ P. capsici } & WPC0253 & Cacao & Mexico & - & - \\
\hline & NBRC30696 & Cucurbita sp. & Japan & - & - \\
\hline P. cinnamomi & NBRC33182 & Hypericum androsaemum & Japan & - & - \\
\hline P. citropthora & WPC1200 & Cacao & Brazil & - & - \\
\hline P. clandestina & CBS347.86 & Trifolium subterraneum & Australia & - & - \\
\hline P. erythroseptica & WPC0340 & Potato & Australia & - & - \\
\hline P. hedraiandra & CBS111725 & Viburnum sp. & Netherlands & - & - \\
\hline P. heveae & WPC1102 & Avocado & Guatemala & - & - \\
\hline P. humicola & WPC3826 & NA & Taiwan & - & - \\
\hline P. idaei & CBS971.95 & Rubus idaeus & UK & - & - \\
\hline P. infestans & CBS368.51 & Solanum tuberosum & Netherlands & - & - \\
\hline P. insolita & WPC6159 & NA & NA & - & - \\
\hline P. ipomoeae & CBS122203 & Ingolfiella longipes & Mexico & - & - \\
\hline P. iranica & CBS374.72 & Solanum melongena & Iran & - & - \\
\hline P. meadii & WPC3500 & NA & NA & - & - \\
\hline P. medicaginis & WPC7029 & Alfalfa & United States & - & - \\
\hline P. megasperma & WPC3163 & NA & United States & - & - \\
\hline P. melonis & WPC1371 & Cucumber & NA & - & - \\
\hline P. mirabilis & CBS678.85 & Mirabilis jalapa & Mexico & - & - \\
\hline P. multivesiculata & CBS545.96 & Cymbidium sp. & Netherlands & - & - \\
\hline P. palmivora & WPC0113 & Papaya & United States & - & - \\
\hline P. phaseoli & CBS120373 & Phaseolus lunatus & United States & - & - \\
\hline P. pseudotsugae & CBS444.84 & Pseudotsuga menziesii & United States & - & - \\
\hline$P$. richardiae & WPC7788 & Carrot & United Kingdom & - & - \\
\hline P. sojae & NBRC31016 & Glycine max & Japan & - & - \\
\hline P. tentaculata & $\mathrm{C} 45$ & Calendula arvensis & Chiba, Japan & - & - \\
\hline P. undulata & WPC7505 & NA & NA & - & - \\
\hline P. vignae & HoAz1 & Azki bean & Hokkaido, Japan & - & - \\
\hline Plasmodiophora brassicae & An & Chinese cabbage & Mie, Japan & - & - \\
\hline Pythium helicoides & CBS286.31 & Phaseolus vulgaris & United States & - & - \\
\hline P. irregulare & NBRC100108 & Carrot & Gifu, Japan & - & - \\
\hline P. myriotylum & NBRC100113 & Kidney bean & Hokkaido, Japan & - & - \\
\hline P. ostracodes & CBS768.73 & Soil & Spain & - & - \\
\hline$P$. paddicum & NBRC31993 & Hordeum vulgare & Japan & - & - \\
\hline P. pyrilobum & NBRC32560 & Agrostis palustris & NA & - & - \\
\hline P. spinosum & NBRC100116 & Soil & Gifu, Japan & - & - \\
\hline P. sylvaticum & NBRC100119 & Soil & Gifu, Japan & - & - \\
\hline P. ultimum & NBRC100123 & Soil & Gifu, Japan & - & - \\
\hline P. vexans & MS6-10-8V & Soil & Gifu, Japan & - & - \\
\hline Pyrenochaeta lycopercisi & Type1 & Tomato & Japan & - & - \\
\hline Rhizoctonia solani & RGR38 & NA & Japan & - & - \\
\hline Saprolegnia sp. & NBRC32708 & Salmo trutta & NA & - & - \\
\hline Verticillium albo-atrum & Vaal 130308 & NA & NA & - & - \\
\hline V. dahliae & Vd84034 & NA & NA & - & - \\
\hline
\end{tabular}

a Symbols: $+=$ amplified, $-=$ no amplification, and $\mathrm{NA}=$ not available.

${ }^{\mathrm{b}}$ Isolates were collected from Centraalbureau fur Schimmelcultures (CBS), NITE Biological Research Centre (NBRC), World Phytophthora Genetic Resource Collection WPC), and Gifu University Cultures Collection.

c Specific primers Nic-F1 and Nic-R1 were designed based on the internal transcribed spacer region for $P$. nicotianae.

d Specific primers Cac-F3 and Cac-R3-2 were designed based on Ypt1 gene for P. cactorum. 
Hokkaido Prefectures) throughout Japan were collected for the survey of pathogen distribution in the summer of 2010 after strawberry cultivation. In each field, five subsamples (each about $100 \mathrm{~g}$ ) were randomly collected and mixed thoroughly. From the soil mixture, approximately $200 \mathrm{~g}$ were recovered and stored at $5^{\circ} \mathrm{C}$. Soil $\mathrm{pH}$ was measured in $1 \mathrm{M}$ potassium chloride. Soil groups and textures were determined according to the classification of the Japanese Ministry of Land, Infrastructure, Transport and Tourism, and the criterion of the International Society of Soil Science, respectively. Disease histories of the fields were provided by local agriculture research centers.

DNA extraction from mycelia and soil. Total genomic DNA from mycelia was extracted according to the procedure of Kageyama et al. (13). Mycelia grown on V8 juice broth medium were used for DNA extraction from culturable species. For soil DNA extraction, the method refined by Kageyama et al. (13) was modified by incorporating a magnetic bead purification step (MagExtractor-Plant Genome; Toyobo Co., Ltd., Osaka, Japan) to purify soil DNA extracts as described by Li et al. (20). Briefly, 0.2 $\mathrm{g}$ of soil was added to autoclaved 2.0-ml Eppendorf tubes containing $0.2 \mathrm{~g}$ of $1-\mathrm{mm}$-diameter glass beads. The soil was suspended in $250 \mu \mathrm{l}$ of extraction buffer $(100 \mathrm{mM}$ Tris $\cdot \mathrm{HCl}$ [pH 9.0], $40 \mathrm{mM}$ EDTA, 2\% [wt/vol] sodium dodecyl sulfate, $0.8 \%$ [wt/vol] skim milk; Difco Laboratories, Detroit), and RNase A at $200 \mu \mathrm{g} / \mathrm{ml}$ (Nippongene, Toyama, Japan), and then vigorously vortexed at 4,200 rpm for $1 \mathrm{~min}$. Benzyl chloride $(150 \mu \mathrm{l})$ was added to the mixture, and the tube was vigorously vortexed for $2 \mathrm{~min}$. After 15 min of incubation at $60^{\circ} \mathrm{C}, 150 \mu \mathrm{l}$ of $3 \mathrm{M} \mathrm{NaOAc}$ was added to the suspension and the mixture was lightly vortexed. After $15 \mathrm{~min}$ of incubation on ice, this suspension was cleared by two rounds of centrifugation at $18,000 \times g$ for $10 \mathrm{~min}$, and the upper layer was transferred to a clean tube. Purification of the extracted DNA was performed according to the manufacturer's instructions in the purification step of the MagExtractor-Plant Genome kit. Finally, 50 $\mu \mathrm{l}$ of the purified DNA was obtained.

Sequencing. The Ypt 1 gene of was sequenced in 19 Phytophthora isolates (Table 2). To amplify the Ypt1 genes of Phytophthora spp., the Phytophthora genus-specific primers Yph1F and Yph2R (Table 3) were used in PCR. The reaction mixture contained $1 \mu \mathrm{M}$ each primer, 1 unit of rTaq DNA polymerase (Takara Bio Inc., Shiga, Japan), $0.2 \mathrm{mM}$ dNTP mixture, $1 \times$ PCR buffer (10 $\mathrm{mM}$ Tris- $\mathrm{HCl}$ [pH 8.3], $50 \mathrm{mM} \mathrm{KCl}$, and $1.5 \mathrm{mM} \mathrm{MgCl}_{2}$ ), $10 \mathrm{ng}$ of bovine serum albumin (Sigma-Aldrich, St. Louis), and about $50 \mathrm{ng}$ of DNA template in a total volume of $25 \mu$. PCR was conducted in a DNA thermal cycler (Gene Amp PCR System 2700; Applied Biosystems, Foster City, CA), under the following conditions: $95^{\circ} \mathrm{C}$ for $2 \mathrm{~min}$; 35 cycles of denaturation at $94^{\circ} \mathrm{C}$ for $30 \mathrm{~s}$, annealing at $58^{\circ} \mathrm{C}$ for $45 \mathrm{~s}$, and extension at $72^{\circ} \mathrm{C}$ for $30 \mathrm{~s}$; followed by a final extension step at $72^{\circ} \mathrm{C}$ for $10 \mathrm{~min}$.

After purification of the PCR products, a BigDye Terminator ver. 3.1 Cycle Sequencing kit (Applied Biosystems) was used for cycle sequencing and run on an ABI PRISM 3100 genetic analyzer (Applied Biosystems). Consensus sequences were generated based on the forward and reverse sequences using Chromas Pro (ver. 1.33; Technelysium Pty. Ltd., Tewantin, Australia).

Primer design. A collection of the ITS region sequences, including 52 Phytophthora spp. and three Pythium spp., were aligned (BioEdit ver. 7.0.0; Isis Pharmaceuticals Inc., Dublin) to design specific primers for $P$. nicotianae. Similarly, an alignment of the Ypt 1 gene sequences from 42 Phytophthora spp. and three Pythium spp. was produced to define specific primers for $P$. cactorum. All of the ITS sequences and $29 Y p t 1$ gene sequences were collected from the DNA database, and another 19 Ypt 1 gene sequences were sequenced in this study (Table 2). Candidate primers were analyzed for dimer and hairpin loop structures (Primer Premier ver. 5.0; Premier Biosoft International, Inc., CA).

Simplex PCR with species-specific primers. Specificity of each developed primer pair was confirmed in simplex PCR with all the isolates listed in Table 1 . The reaction mixture contained $1 \mu \mathrm{M}$ developed primers, 1 unit of FastStart Taq DNA polymerase
(Roche Applied Science, Mannheim, Germany), $0.2 \mathrm{mM}$ dNTP mixture, $1 \times$ PCR buffer $(10 \mathrm{mM}$ Tris- $\mathrm{HCl}[\mathrm{pH} 8.3], 50 \mathrm{mM} \mathrm{KCl}$, and $1.5 \mathrm{mM} \mathrm{MgCl}_{2}$ ), $10 \mathrm{ng}$ of bovine serum albumin (Sigma-Aldrich), and about $50 \mathrm{ng}$ of DNA template in a total volume of 25 $\mu \mathrm{l}$. PCR was conducted in a DNA thermal cycler (Gene Amp PCR System 2700) at $95^{\circ} \mathrm{C}$ for $5 \mathrm{~min}$; followed by 35 cycles of denaturation at $95^{\circ} \mathrm{C}$ for $30 \mathrm{~s}$, annealing at $66^{\circ} \mathrm{C}$ for $30 \mathrm{~s}$, and extension at $72^{\circ} \mathrm{C}$ for $1 \mathrm{~min}$; with a final extension at $72^{\circ} \mathrm{C}$ for $10 \mathrm{~min}$.

Specificity was compared among five published primer pairs (Pn5B/Pn6, $\mathrm{P}_{\mathrm{NIC}} 1 / \mathrm{P}_{\mathrm{NIC}} 2$, PN-F/PN-R, IL7/IL8, and Pn1/Pn2) designed for $P$. nicotianae and three primer pairs (Ycac1F/Ycac2R, BPhycacL87FRG/BPhycacR87RRG, and BPhycacL89FRG/ BPhycacR176RRG) for P. cactorum. PCR was performed according to the protocols provided in the original article reporting the primer pairs. Thirteen closely related Phytophthora spp., including $P$. nicotianae, $P$. cactorum, $P$. hedraiandra, $P$. idea, $P$. pseudotsugae, $P$. clandestine, $P$. iranica, $P$. tentaculata, $P$. infestans, $P$. ipomoeae, $P$. mirabilis, $P$. phaseoli, and $P$. multivesiculata, were used for specificity test. Amplification was confirmed by electrophoresis in 3\% certified low-range ultra agarose (Bio-Rad Laboratories, Hercules, CA). Gels were stained with ethidium bromide and photographed under ultraviolet light.

Multiplex PCR. As a positive control to ensure the success of DNA extraction, two universal primers, $18 \mathrm{~S}-69 \mathrm{~F}$ and $18 \mathrm{~S}-1118 \mathrm{R}$ (Table 3), were added to the multiplex PCR reaction mixture. Magnesium chloride was added to improve the amplification of multiloci. The multiplex PCR reaction mixture was prepared as described for simplex PCR, except that the final concentrations of $\mathrm{MgCl}_{2}$ and the primer pairs 18S-69F/18S-1118R, P. nicotianaespecific primer pair Nic-F1/Nic-R1, and $P$. cactorum-specific primer pair Cac-F3/Cac-R3-2 were $3 \mathrm{mM}, 0.25 \mu \mathrm{M}, 1 \mu \mathrm{M}$, and 2 $\mu \mathrm{M}$, respectively. Reaction conditions were the same as in simplex PCR. PCR products were electrophoresed in $3 \%$ certified lowrange ultra agarose.

The applicability of the multiplex PCR was tested using soil samples from six strawberry-growing locations with $P$. nicotianae disease histories and two artificially infested soil samples. Two samples from locations with $P$. cactorum disease histories were analyzed as well. Pure culture DNA mixtures of the two species served as a positive control.

Sensitivity tests. Sensitivity to $P$. nicotianae and $P$. cactorum DNA was tested in both simplex PCR and multiplex PCR. Ten-fold dilution series (1 $\mathrm{ng}$ to $10 \mathrm{fg}$ ) of DNA from three $P$. nicotianae isolates (CH03OKTYPE3, CH02FPK3, and GF465) and three $P$. cactorum isolates (GF654, CH07INBA1-2, and EID2) were used in simplex PCR. Three DNA mixtures (CH03OKTYPE3 $\times$ GF654, CH02FPK3 $\times$ CH07INBA1-2, and GF465 × EID2), diluted from 1 ng to $10 \mathrm{fg}$, were used in multiplex PCR.

\section{Results}

Primer design. Previously, unknown sequences of the $Y p t 1$ gene were determined in the present study (Table 2). The primers NicF1and Nic-R1 were designed based on the ITS region for specific amplification of $P$. nicotianae. Similarly, the primers Cac-F3 and Cac-R3-2 were designed based on the Ypt1 gene of P. cactorum. The primers were designed for an annealing temperature of over $56^{\circ} \mathrm{C}$.

Specificity confirmation of designed primers and comparison with other primers. In all, 13 and 9 isolates of $P$. nicotianae and $P$. cactorum, respectively, from different hosts and geographic locations in Japan were used together with 45 non-target species (Table 1) to test the specificity of the designed primers for each species. The presence of amplified DNA from all isolates was confirmed using the primers $18 \mathrm{~S}-69 \mathrm{~F}$ and $18 \mathrm{~S}-1118 \mathrm{R}$. The primers Nic-F1 and Nic-R1 only amplified the P. nicotianae isolates with a specific band of 267 bp evaluated by sequence analysis, and Cac-F3 and Cac-R3-2 exclusively amplified the P. cactorum isolates with a unique band of $223 \mathrm{bp}$ evaluated by sequence analysis. The two target bands were clearly distinguished in electrophoresis. 
For the detection of $P$. nicotianae and $P$. cactorum, several specific primers were developed previously (Table 3 ). We compared their specificity using 13 closely related Phytophthora spp. belonging to clade 1 according to Blair et al. (3). First DNA amplification was performed using the two universal primers pairs ITS1/ITS4 and 18S-69F/18S-1118R (Fig. 1). The Nic-F1/Nic-R1 primers amplified the expected 267-bp fragment only from $P$. nicotianae. The Pn5B/Pn6 primers amplified the same size of DNAs from four species: $P$. nicotianae, $P$. cactorum, $P$. hedraiandra, and $P$. idaei. The PN-F/PN-R primers amplified the same size of segments from $P$. nicotianae and $P$. cactorum. The primers $\mathrm{P}_{\mathrm{NIC}} 1 / \mathrm{P}_{\mathrm{NIC}} 2$, IL7/IL8, and $\mathrm{Pn} 1 / \mathrm{Pn} 2$ produced a signal with DNA from $P$. nicotianae; a slight amplicon of the same size from $P$. cactorum was found as well (Fig. 1).

With $P$. cactorum DNA, Cac-F3/Cac-R3-2 amplified a segment of $223 \mathrm{bp}$ but Ycac1F/Ycac2R and BPhycacL87FRG/

Table 2. Accession number of the sequences of the internal transcribed spacer region and Ypt 1 gene in DNA database ${ }^{\mathrm{a}}$

\begin{tabular}{|c|c|c|c|c|}
\hline \multirow[b]{2}{*}{ Species } & \multicolumn{2}{|c|}{ ITS region } & \multicolumn{2}{|c|}{ Ypt1 gene } \\
\hline & Isolates & Accession & Isolates & Accession \\
\hline \multirow[t]{3}{*}{ Phytophthora nicotianae } & P1452 & FJ801769 & IMI268688 & DQ162981 \\
\hline & P7146 & FJ801963 & $\mathrm{CH} 02 \mathrm{FPK}^{3}{ }^{\mathrm{b}}$ & HQ849999 \\
\hline & P11000 & FJ801542 & & \\
\hline \multirow[t]{3}{*}{ P. cactorum } & CH98PEC1 & AB367364 & IMI296524 & DQ162960 \\
\hline & CH03 OKTYPE1 & AB367366 & CH03OKTYPE1 ${ }^{\mathrm{b}}$ & HQ850000 \\
\hline & СH02MKPY001 & AB367365 & $\mathrm{EID} 2^{\mathrm{b}}$ & HQ850001 \\
\hline P. alni subsp. alni & P16203 & GU259292 & SCRP2 & DQ162953 \\
\hline P. bisheria & Cg.2.3.3 & AY241924 & $\mathrm{N}$ & $\mathrm{N}$ \\
\hline P. botryosa & P6945 & FJ801954 & $\mathrm{N}$ & $\mathrm{N}$ \\
\hline P. cambivora & P0592 & GU259025 & SCRP82 & DQ162956 \\
\hline P. capsici & P1091 & GU259193 & IMI352321 & DQ162972 \\
\hline P. chrysanthemi & GF749 & AB437135 & $\mathrm{N}$ & $\mathrm{N}$ \\
\hline P. cinnamomi & P3232 & GU594781 & CBS270.55 & DQ162959 \\
\hline P. citricola & P7902 & GU259136 & SCRP143 & DQ162971 \\
\hline P. citrophthora & P6310 & FJ801913 & IMI332632 & DQ162973 \\
\hline$P$. clandestina & P3942 & FJ801888 & CBS347.86 & HQ850002 \\
\hline P. colocasiae & P6318 & GU258989 & $\mathrm{N}$ & $\mathrm{N}$ \\
\hline P. cryptogea & CBS290.35 & AF228099 & IMI045168 & DQ162987 \\
\hline P. drechsleri & P10331 & FJ801387 & ATCC46724 & DQ162989 \\
\hline P. erythroseptica & CBS 956.87 & AF228082 & SCRP240 & DQ162988 \\
\hline P. europaea & CBS109049 & DQ275190 & SCRP622 & DQ162952 \\
\hline P. fragariae var. fragariae & & AF266762 & SCRP245 & DQ162950 \\
\hline P. hedraiandra & P11056 & EU080072 & CBS $111725^{b}$ & HQ850003 \\
\hline P. idaei & P6767 & FJ801946 & CBS971.95 & HQ850004 \\
\hline P. ilicis & P2159 & AY302164 & SCRP379 & DQ162963 \\
\hline P. infestans & P10650 & FJ801470 & CBS368.51 $1^{\mathrm{b}}$ & HQ850005 \\
\hline$P$. inflate & IMI342898 & AF266789 & $\mathrm{N}$ & $\mathrm{N}$ \\
\hline P. insolita & IMI288805 & AF271222 & IMI288805 & DQ162974 \\
\hline P. inundata & P8478 & FJ802005 & SCRP649 & DQ162985 \\
\hline P. ipomoeae & $\mathrm{P} 10225$ & FJ801323 & CBS $122203^{b}$ & HQ850006 \\
\hline P. iranica & CBS374.72 & L41378 & $\mathrm{CBS} 374.72^{\mathrm{b}}$ & HQ850007 \\
\hline P. katsurae & P10187 & GU259517 & SCRP388 & DQ162980 \\
\hline P. kernoviae & P1571 & AY940661 & SCRP722 & DQ162975 \\
\hline P. lateralis & P3888 & FJ802093 & IMI040503 & DQ162991 \\
\hline P. meadii & P6128 & GU259180 & $\mathrm{N}$ & $\mathrm{N}$ \\
\hline P. medicaginis & P10683 & GU259090 & SCRP407 & DQ162990 \\
\hline P. megakarya & P8516 & FJ802010 & $\mathrm{P} 8517^{\mathrm{b}}$ & HQ850008 \\
\hline P. megasperma & P3136 & GU258789 & IMI133317 & DQ162986 \\
\hline P. melonis & P10994 & FJ801540 & PMNJHG1 & EF649778 \\
\hline P. mexicana & P0646 & FJ801253 & $\mathrm{N}$ & $\mathrm{N}$ \\
\hline P. mirabilis & P3005 & FJ802098 & CBS678.85 & HQ850009 \\
\hline P. multivesiculata & CBS545.96 & DQ988192 & CBS545.96 & HQ850010 \\
\hline P. nemorosa & P10288 & FJ801359 & SCRP910 & DQ162965 \\
\hline P. palmivora & P0255 & FJ801246 & $\mathrm{IPPc}^{\mathrm{b}}$ & HQ850011 \\
\hline P. parsiana & $\mathrm{C} 25$ & AY659739 & $\mathrm{N}$ & $\mathrm{N}$ \\
\hline P. phaseoli & P10145 & FJ802106 & CBS $120373^{b}$ & HQ850012 \\
\hline P. pistaciae & P6197 & FJ801904 & IMI386658 & DQ162957 \\
\hline P. polonica & $\mathrm{P} 131445$ & AB511828 & $\mathrm{N}$ & $\mathrm{N}$ \\
\hline P. pseudosyringae & P10437 & FJ801438 & SCRP734 & DQ162967 \\
\hline P. pseudotsugae & IMI331662 & AF266774 & CBS444.84 ${ }^{\mathrm{b}}$ & HQ850013 \\
\hline P. psychrophila & P10433 & FJ801435 & SCRP630 & DQ162964 \\
\hline P. quercina & CBS 115973 & AY853200 & SCRP550 & DQ162979 \\
\hline P. ramorum & P10301 & FJ801362 & SCRP911 & DQ162992 \\
\hline P. richardiae & RICH-P7789 & AB367498 & $\mathrm{N}$ & $\mathrm{N}$ \\
\hline P. sojae & P3114 & FJ801828 & SCRP555 & DQ162958 \\
\hline P. tentaculata & CBS552.96 & AF266775 & $\mathrm{C} 45^{\mathrm{b}}$ & HQ850014 \\
\hline Pythium oedochilum & $\mathrm{N}$ & $\mathrm{N}$ & CBS597.68 & HQ850015 \\
\hline P. helicoides & H5sz1C14 & AB 108025 & $\mathrm{TCG}^{\mathrm{b}}$ & HQ850016 \\
\hline P. ostracodes & $\mathrm{N}$ & $\mathrm{N}$ & CBS768.73 & HQ850017 \\
\hline P. undulatum & & AF271230 & $\mathrm{N}$ & $\mathrm{N}$ \\
\hline P. vexans & CBS 119.80 & AY598713 & $\mathrm{N}$ & $\mathrm{N}$ \\
\hline
\end{tabular}

${ }^{a} \mathrm{~N}=$ species not used for this DNA region.

$\mathrm{b}$ Isolates sequenced in this study. 
BPhycacR87RRG amplified DNA sequences from $P$. hedraiandra, $P$. idaei, and P. pseudotsugae as well. No amplification by BPhycacL89FRG/BPhycacR176RRG was found (Fig. 2).

Sensitivity test. In simplex, the primers Nic-F1/Nic-R1 detected as little as $100 \mathrm{fg}$ of DNA of P. nicotianae isolate CH03OKTYPE3 (Fig. 3A). The same sensitivity was also obtained in the other two $P$. nicotianae isolates, CH02FPK3 and GF465. The primers CacF3/Cac-R3-2 detected down to $1 \mathrm{pg}$ of DNA of $P$. cactorum isolate GF654 (Fig. 3B). In the other two $P$. cactorum isolates, CH07INBA1-2 and EID2, the same sensitivity was obtained as well. In multiplex PCR, the same sensitivity as in simplex PCR was obtained from all DNA mixtures: CH03OKTYPE3 $\times$ GF654 (Fig. 3C), CH02FPK3 $\times$ CH07INBA1-2, and GF465 $\times$ EID2 .

Application of the multiplex PCR in naturally and artificially infested soils. Using the naturally and artificially infested soils, the multiplex PCR with primer pairs Nic-F1/Nic-R1, CacF3/Cac-R3-2, and 18S-69F/18S-1118R amplified the segments obtained by the universal primers $18 \mathrm{~S}-69 \mathrm{~F} / 18 \mathrm{~S}-1118 \mathrm{R}$ in all samples (Fig. 4). In the samples infested with $P$. nicotianae, NicF1/Nic-R1 amplified a specific DNA segment. In the samples infested with $P$. cactorum, Cac-F3/Cac-R3-2 amplified a specific DNA segment as well.

Distribution of $P$. nicotianae and $P$. cactorum in the main strawberry production areas of Japan. Although the soil samples showed different soil textures and soil groups (Table 4), the universal primers $18 \mathrm{~S}-69 \mathrm{~F}$ and $18 \mathrm{~S}-1118 \mathrm{R}$ amplified DNA in all samples, indicating that DNA extraction had been performed successfully in all soil samples from 89 fields. In all, 10 samples had an anthracnose history and 6 had a Fusarium wilt history; neither $P$. nicotianae nor $P$. cactorum were detected in these 16 samples. Two samples (Chiba 1 and Saga 1) had a Phytophthora rot history. $P$. nicotianae as well as $P$. cactorum were detected in Saga 1 but neither was detected in Chiba 1. Moreover, among the samples without disease history, $P$. nicotianae was detected in two samples from Nara Prefecture and two from Saga, while P. cactorum was detected in one sample from Nara and one from Yamanashi.

In summary, neither of the two species was found in the Gifu, Chiba, Shizuoka, Tochigi, and Hokkaido Prefectures, while both were found in Nara and Saga Prefectures; only P. cactorum was found in Yamanashi Prefecture.

\section{Discussion}

In this study, we developed a reliable method to identify and detect $P$. nicotianae and $P$. cactorum simultaneously. Species-specific primer pairs were designed in the ITS region and the Ypt 1 gene for $P$. nicotianae and $P$. cactorum, respectively. Multiplex PCR was optimized and successfully applied to survey both species in soil.

Primer designing is crucial for PCR-based diagnosis. In preliminary tests, we examined nine DNA loci, including the rDNA ITS region, $28 \mathrm{~S}$ rDNA, the $60 \mathrm{~S}$ ribosomal protein L10 gene, the $\beta$ tubulin gene, the elongation factor $1 \alpha$ gene, the enolase gene, the heat shock protein 90 gene, the tigA gene fusion protein sequence, and Ypt1. When the sequences of species of the Phytophthora clade 1 (described by Blair et al. [3]), which is closely related to $P$. nicotianae and $P$. cactorum, were compared to identify interspecies variations suitable for the definition of specific primers, the ITS region and the Ypt 1 gene emerged as promising candidates. We successfully designed primers based on the ITS region for $P$. nicotianae. Only the $Y p t 1$ gene proved to be a suitable target for primers specific to $P$. cactorum.

The ITS regions of rDNA are useful targets for fungal speciesspecific primers due to their high copy number, sequence variability, and fidelity among pathogen species or subspecies. Therefore, in recent years, they were widely used to identify and detect Phytophthora spp. However, sequence variations in this region between closely related species are not always sufficient to define highly specific primers. Two primer pairs (Pn5B/Pn6 and $\mathrm{P}_{\mathrm{NIC}} 1 / \mathrm{P}_{\mathrm{NIC}} 2$ ) were designed based on the ITS regions of $P$. nicotianae by Ippolito et al. (11) and Grote et al. (9), respectively. However, Pn5B and Pn6 could not discriminate P. cactorum, $P$. hedraiandra, and $P$. idaei in the specificity test (Fig. 1). $\mathrm{P}_{\mathrm{NIC}} 1$ and $\mathrm{P}_{\mathrm{NIC}} 2$ amplified a sequence from $P$. nicotianae but also from $P$. cactorum isolate GF654. We designed the two primers Nic-F1 and Nic-R1 that target ITS regions of $P$. nicotianae with high specificity. Moreover, the two primer pairs PN-F/PN-R and IL7/IL8, targeting the elicitin gene ParA1, and the primer pair $\mathrm{Pn} 1 / \mathrm{Pn} 2$, targeting the $Y p t 1$ gene, were used for the comparison of specificities. PN-F and PN-R could not separate $P$. nicotianae and $P$. cactorum. The primers IL7/IL8 and Pn1/Pn2 reacted to $P$. cactorum isolate GF654. To overcome the low specificity of the primers of

Table 3. Primers used in this study

\begin{tabular}{|c|c|c|c|c|c|}
\hline Target species & Primers $^{\mathrm{a}}$ & Gene locus $^{\text {b }}$ & Sequence $\left(5^{\prime}-3^{\prime}\right)$ & Target size (bp) & Reference \\
\hline \multirow[t]{4}{*}{ Fungi } & ITS1 & ITS region & TCCGTAGGTGAACCTGCGG & Variable & 28 \\
\hline & ITS4 & & TCCTCCGCTTATTGATATGC & & \\
\hline & $18 \mathrm{~S} 69 \mathrm{~F}$ & 18S rDNA & CTGCGAATGGCTCATTAAATCAGT & Variable & 1 \\
\hline & $18 \mathrm{~S} 1118 \mathrm{R}$ & & GGTGGTGCCCTTCCGTCAA & & \\
\hline \multirow[t]{2}{*}{ Phytophthora spp. } & YPh1F & $Y p t 1$ gene & CGACCATKGGTGTGGACTTT & Variable & 23 \\
\hline & YPh2R & & ACGTTCTCMCAGGCGTATCT & $\approx 470$ & \\
\hline \multirow[t]{12}{*}{ Phytophthora nicotianae } & Nic-F1 & ITS region & CCTATCAAAAACAAGGCGAACG & 267 & This study \\
\hline & Nic-R1 & & TGGCATACTTCCAGGACTAACC & & \\
\hline & Pn5B & ITS region & GAACAATGCAACTTATTGGACGTTT & 120 & 11 \\
\hline & Pn6 & & AACCGAAGCTGCCACCCTAC & & \\
\hline & $\mathrm{P}_{\mathrm{NIC}} 1$ & ITS region & CAATAGTTGGGGGTCTTATT & 737 & 9 \\
\hline & $\mathrm{P}_{\mathrm{NC}}^{2} 2$ & & GTATACCGAAGTACACATTAAG & & \\
\hline & PN-F & Elicitin gene parAl & CCACCACGCAGCAAACTGCGGC & 230 & 16 \\
\hline & PN-R & & TTGAGTACCAGGCCGCTCGTAG & & \\
\hline & IL7 & Elicitin gene parAl & CTCCAGCTAGTCAAGCCTAGT & 378 & 18 \\
\hline & IL8 & & GCACCGTCAACTCGCAGTC & & \\
\hline & Pn1 & Ypt 1 gene & GACTTTGTAAGTGCCACCATAC & 389 & 21 \\
\hline & Pn2 & & CTCAGCTCTTTTCCTTGGATCT & & \\
\hline \multirow[t]{8}{*}{ P. cactorum } & Cac-F3 & $Y p t 1$ gene & CGTGGCGTGTTTCCTATTC & 223 & This study \\
\hline & Cac-R3-2 & & TTCCGTCGGCTCTTTCAG & & \\
\hline & Ycac1F & Ypt 1 gene & CCATACAAAATTCTGCGCTAGG & 194 & 23 \\
\hline & Ycac2R & & AGACACACAAGTGGACCGTTAG & & \\
\hline & BPhycacL87FRG & ITS region & CTTCGGCCTGAGCTAGTAGCT & 340 and 480 & 2 \\
\hline & BPhycacR87RRG & & CAGTCGGTCCGAAAACCAG & & \\
\hline & BPhycacL89FRG & ITS region & GGCTTCGGCCTGAGCTAGTAGCT & 431 & 2 \\
\hline & BPhycacR176RRG & & CAACTTGCTACAATA & & \\
\hline
\end{tabular}

\footnotetext{
a Primers in bold are designed in this study.

${ }^{\mathrm{b}}$ ITS $=$ internal transcribed spacer and rDNA = ribosomal DNA.
} 
both $P$. nicotianae and $P$. cactorum, optimization of DNA polymerase and dNTP concentration will be needed rather than PCR condition, because the PCR conditions were followed as in the original articles.

Primer design was more complicated for P. cactorum. As described by Blair et al. (3), P. cactorum is phylogenetically closely related to $P$. hedraiandra, $P$. idaei, and $P$. pseudotsugae. For these species, little interspecies variation was present in the nine loci that we scrutinized. In fact, the two primer pairs BPhycacL87FRG/ BPhycacR87RRG and BPhycacL89FRG/BPhycacR176RRG that Bhat et al. (2) had designed based on the ITS regions could not differentiate the four species (Fig. 2). The primers BPhycacL89FRG/BPhycacR176RRG did not amplify. Possibly because the two primers are the second-round primers designed for a nested PCR, direct PCR under high annealing temperature would affect amplification. Even in the Ypt 1 gene, which was found to exhibit
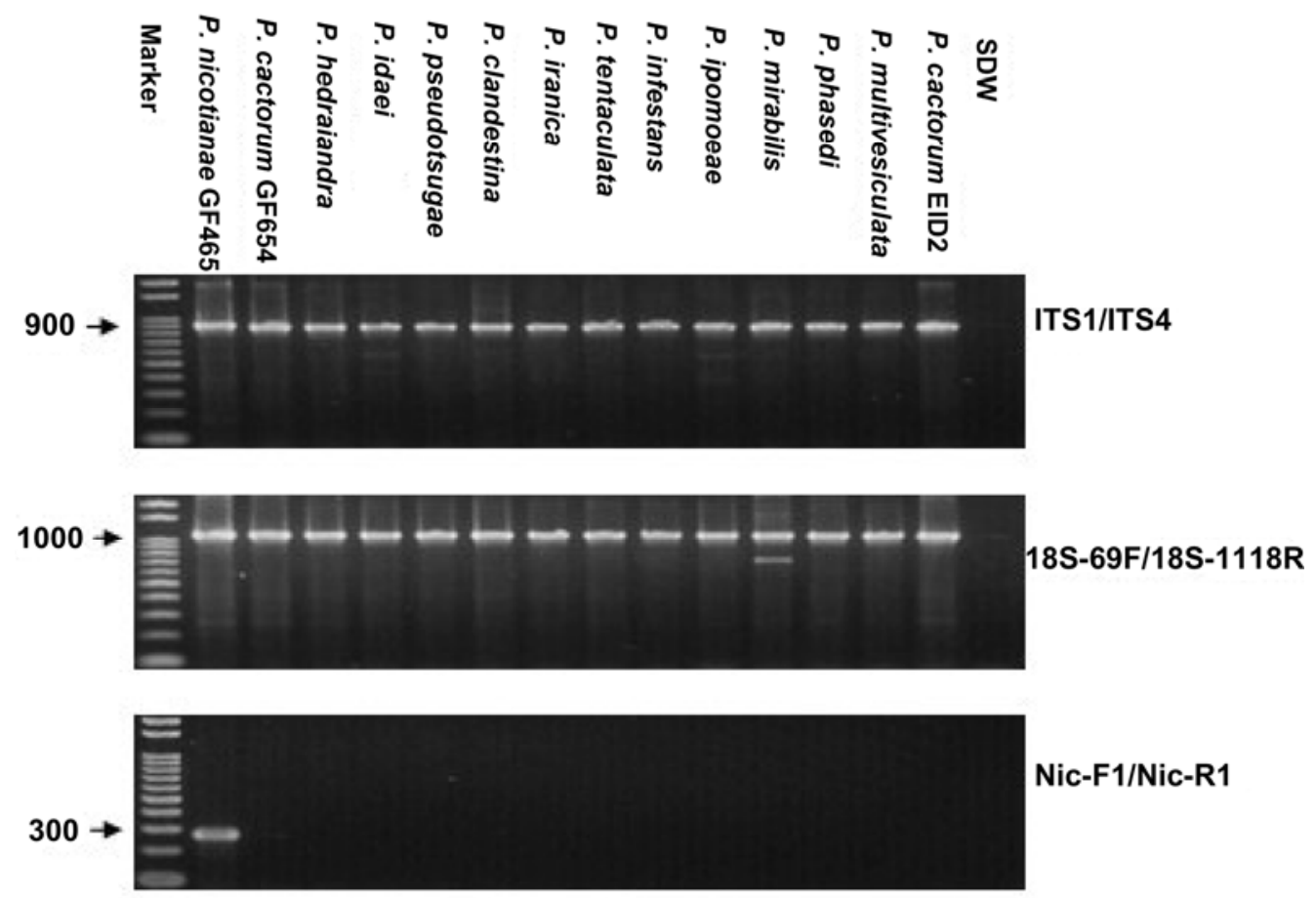

Nic-F1/Nic-R1

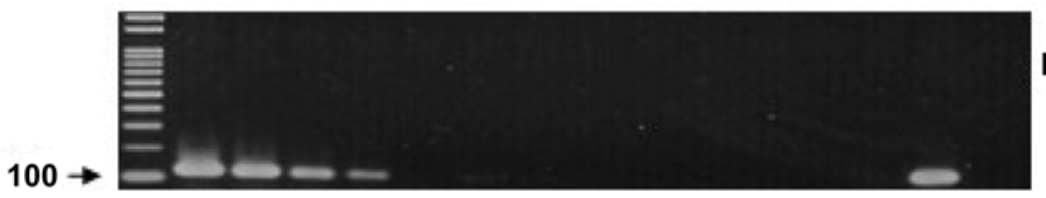

Pn5B/Pn6

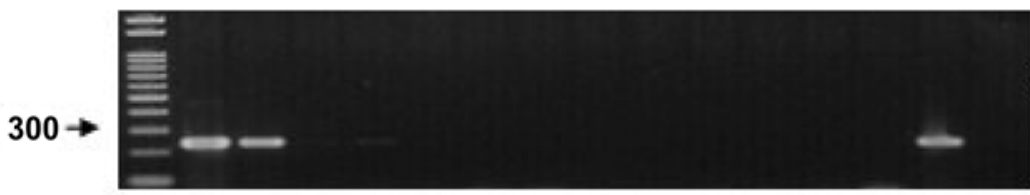

PN-F/PN-R
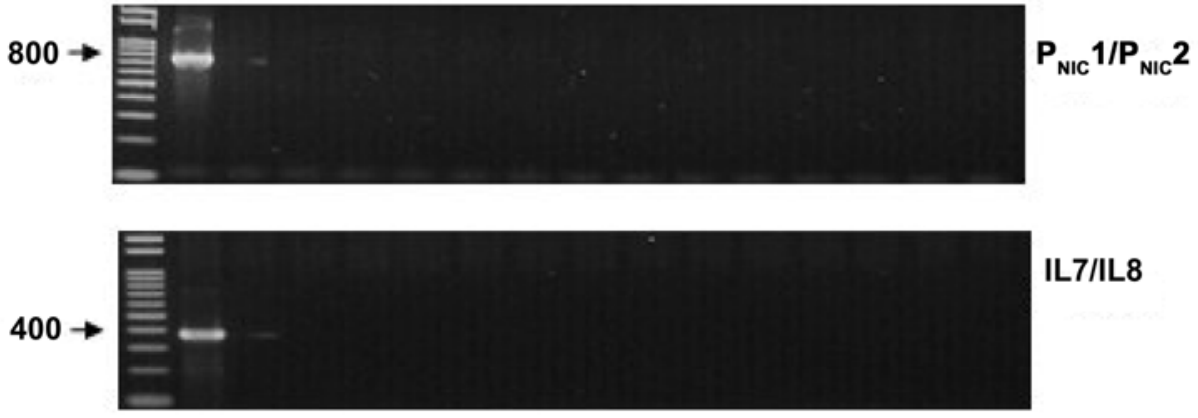

IL7/IL8

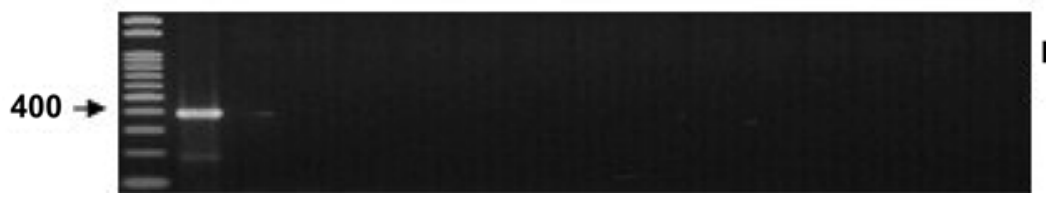

Pn1/Pn2

Fig. 1. Specificity of the designed and the published primer pairs for Phytophthora nicotianae. Thirteen closely related Phytophthora spp. were used to test the specificity of the primer pairs. SDW = sterile distilled water. Size marker: 100-bp DNA ladder. 

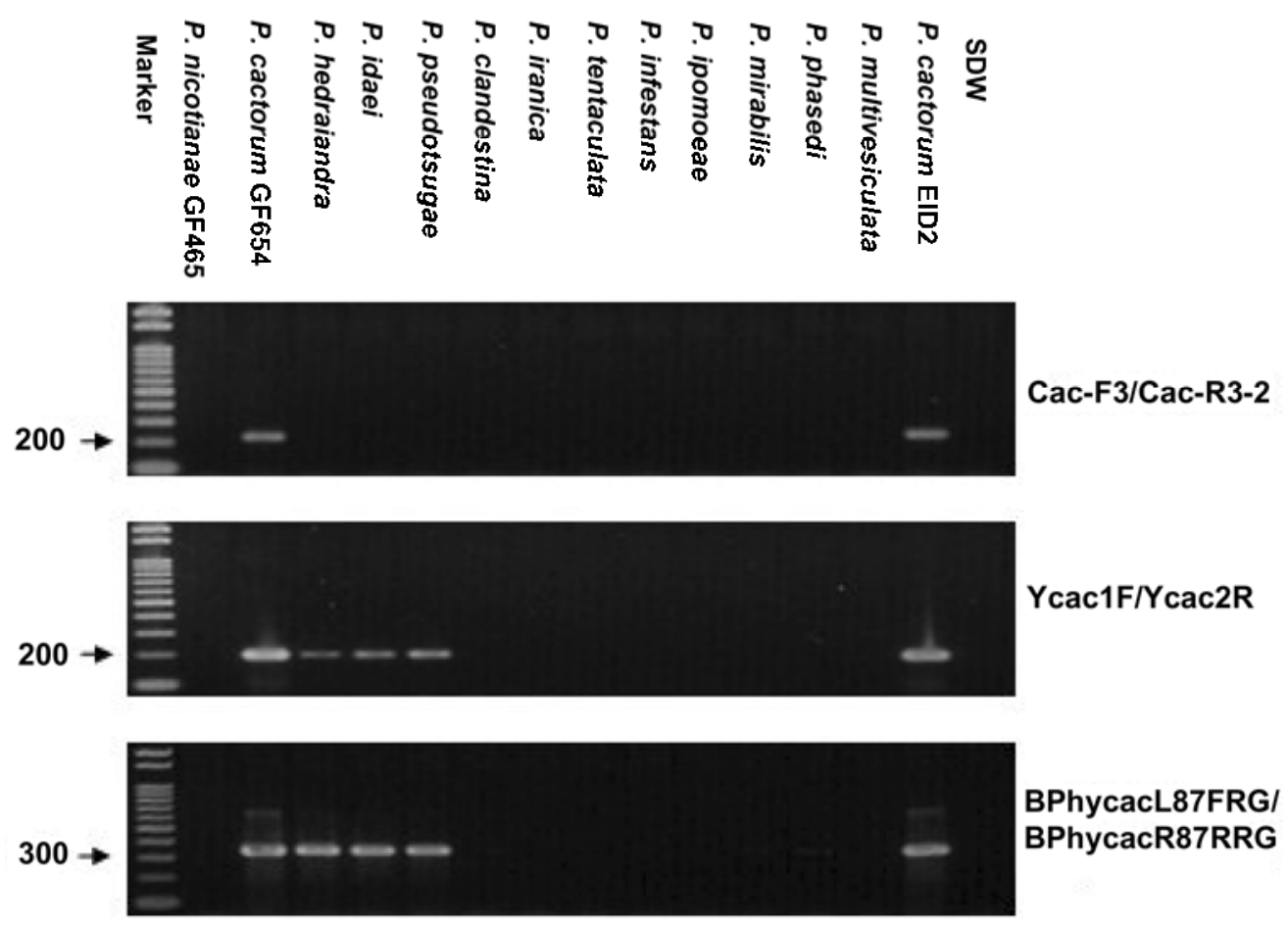

BPhycacL89FRG/

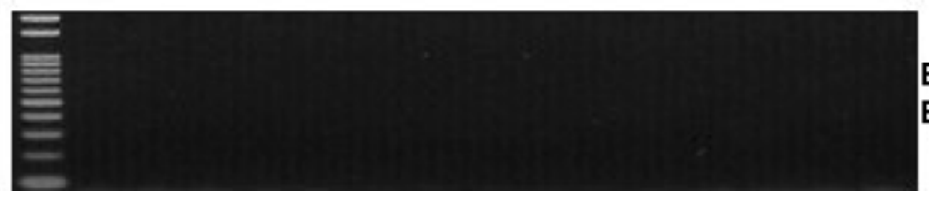

BPhycacR176RRG

Fig. 2. Specificity of the designed and the published primer pairs for Phytophthora cactorum. Thirteen closely related Phytophthora spp. were used. SDW $=$ sterile distilled water. Size marker: 100-bp DNA ladder.

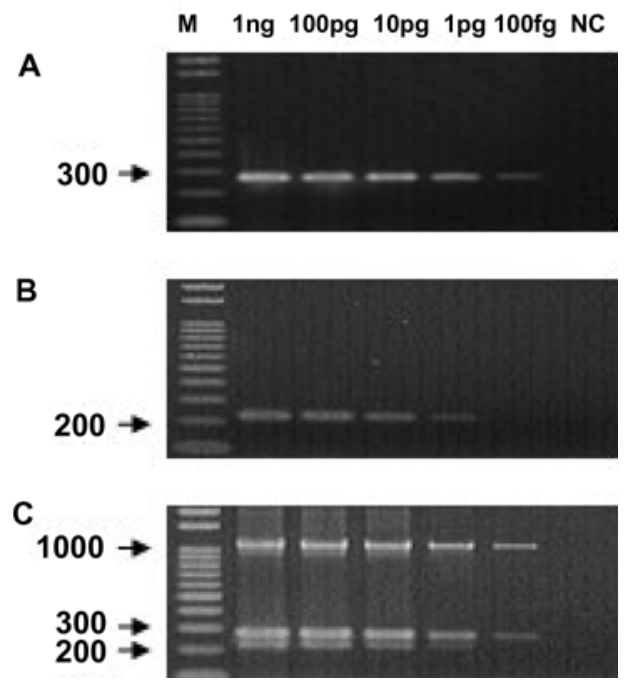

Fig. 3. Detection limits for Phytophthora nicotianae and $P$. cactorum. A, Amplification with species-specific primer pair Nic-F1/Nic-R1 for $P$. nicotianae isolate CH03OKTYPE3. B, Amplification with species-specific primer pair Cac-F3/Cac-R32 for $P$. cactorum isolate GF654. C, Multiplex polymerase chain reaction (PCR) with three primer pairs (18S-69F/18S-1118R, Nic-F1/Nic-R1, and Cac-F3/Cac-R3-2). DNA from pure cultures was diluted from $1 \mathrm{ng}$ to $100 \mathrm{fg}$ and used to test the sensitivity of the primer pairs. For multiplex PCR, the DNA mixtures of $P$. nicotianae isolate CH03OKTYPE3 and $P$. cactorum isolate GF654 were diluted from $1 \mathrm{ng}$ to $100 \mathrm{fg}$. $\mathrm{NC}=$ sterile distilled water as negative control and $\mathrm{M}=100$-bp DNA ladder.

sufficient variation to enable the development of molecular markers for almost all Phytophthora spp., possibilities to design specific primers for $P$. cactorum were limited. Schena et al. (23) developed two primers, Ycac1F and Ycac2R, for P. cactorum using the Ypt 1

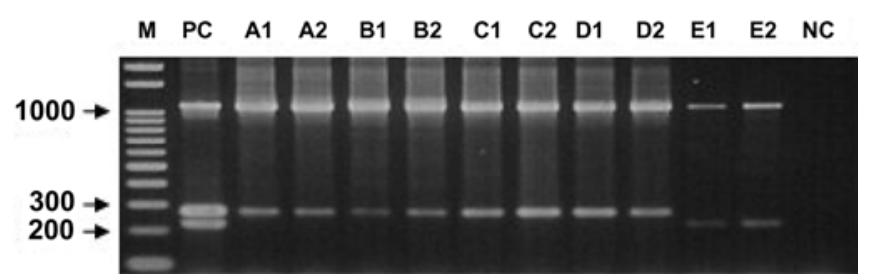

Fig. 4. Multiplex polymerase chain reaction from different soils for the detection of Phytophthora nicotianae and $P$. cactorum. Soil samples A1/A2, B1/B2, C1/C2, D1/D2, and E1/E2 were collected from the Chiba, Nara, Saga, Saga, and Nara Prefectures of Japan, respectively. PC $=$ the mixture of mycelial DNA of $P$. nicotianae and $P$. cactorum as positive control, $\mathrm{NC}=$ sterile distilled water as negative control, and $\mathrm{M}=100-\mathrm{bp}$ DNA ladder.

gene. However, in our tests, these primers could not distinguish $P$. cactorum from $P$. hedraiandra, P. idaei, and P. pseudotsugae (Fig. $2)$. Only one of the Ypt1-based primer pairs that we tested in preliminary experiments, Cac-F3 and Cac-R3-2, was found to reliably identify $P$. cactorum.

Multiplex PCR was successfully performed with three primer pairs: 18S-69F/18S-1118R, Nic-F1/Nic-R1, and Cac-F3/Cac-R3-2. According to the critical parameters in multiplex PCR as discussed by Henegariu et al. (10), we optimized mainly four factors: annealing temperature (AT), buffer concentration, primer amounts, and the balance of dNTP and magnesium chloride. Because co-amplification targeted three different loci in our case, the reactions performed satisfactorily even at high AT. Raising the buffer concentration may improve the efficiency of the multiplex reaction but, when we raised the buffer concentration to $1.6 \times$, the bands amplified by the universal primers (18S-69F/18S-1118R) disappeared (data not shown). Possibly, this occurred because primers with long amplification products would work better at lower salt concentration, whereas primers with a short amplicon would am- 
Table 4. Detection of Phytophthora nicotianae and P. cactorum in the main strawberry production areas of Japan using multiplex polymerase chain reaction

\begin{tabular}{|c|c|c|c|c|c|c|}
\hline Prefectures & Field number & Soil group ${ }^{a}$ & Soil texture $^{b}$ & pH & Disease history $^{c}$ & Detected pathogens \\
\hline \multirow[t]{4}{*}{ Gifu } & 1 & $\mathrm{~N}$ & $\mathrm{~N}$ & $\mathrm{~N}$ & Fusarium wilt & No \\
\hline & 2 & $\mathrm{~N}$ & $\mathrm{~N}$ & $\mathrm{~N}$ & Anthracnose & No \\
\hline & 3 & $\mathrm{~N}$ & $\mathrm{~N}$ & $\mathrm{~N}$ & Anthracnose, Fusarium wilt & No \\
\hline & $4-14$ & $\mathrm{~N}$ & $\mathrm{~N}$ & $\mathrm{~N}$ & $\mathrm{U}$ & No \\
\hline \multirow[t]{4}{*}{ Nara } & 1 & $\mathrm{~N}$ & $\mathrm{~N}$ & $\mathrm{~N}$ & $\mathrm{U}$ & P. nicotianae \\
\hline & 2 & $\mathrm{~N}$ & $\mathrm{~N}$ & $\mathrm{~N}$ & $\mathrm{U}$ & P. cactorum \\
\hline & 3 & 1 & $\mathrm{~L}$ & 5.8 & $\mathrm{U}$ & P. nicotianae \\
\hline & $4-12$ & 1 & $\mathrm{~L}$ & $5.4-6.8$ & $\mathrm{U}$ & No \\
\hline \multirow{3}{*}{ Chiba } & 1 & 2 & $\mathrm{~L}$ & 5.5 & Phytophthora rot & No \\
\hline & 2 & 4 & $\mathrm{~L}$ & 6.6 & Fusarium wilt & No \\
\hline & $3-10$ & $2,4,5,6$ & $\mathrm{~L}, \mathrm{SL}$ & $5.5-7.7$ & $\mathrm{U}$ & No \\
\hline \multirow[t]{4}{*}{ Saga } & 1 & 1 & CL & 5.8 & Phytophthora rot & Both \\
\hline & 2 & $\mathrm{~N}$ & $\mathrm{~N}$ & $\mathrm{~N}$ & $\mathrm{U}$ & P. nicotianae \\
\hline & 3 & $\mathrm{~N}$ & $\mathrm{~N}$ & $\mathrm{~N}$ & $\mathrm{U}$ & P. nicotianae \\
\hline & $4-12$ & 1,3 & $\mathrm{CL}$ & $4.4-6.2$ & $\mathrm{U}$ & No \\
\hline \multirow[t]{5}{*}{ Shizuoka } & 1 & $\mathrm{~N}$ & $\mathrm{~N}$ & 5.3 & Anthracnose & No \\
\hline & 2 & $\mathrm{~N}$ & $\mathrm{~N}$ & 7.1 & Anthracnose & No \\
\hline & 3 & 9 & LS & 5.5 & Anthracnose & No \\
\hline & 4 & 4 & LS & 5.5 & Anthracnose & No \\
\hline & $5-20$ & 5,9 & $\mathrm{~L}, \mathrm{LS}$ & $5.3-7.1$ & $\mathrm{U}$ & No \\
\hline \multirow[t]{6}{*}{ Tochigi } & 1 & 7 & $\mathrm{~L}$ & 4.9 & Anthracnose & No \\
\hline & 2 & 2 & $\mathrm{CL}$ & 5.2 & Fusarium wilt & No \\
\hline & 3 & 8 & $\mathrm{~L}$ & 5.2 & Anthracnose, Fusarium wilt & No \\
\hline & 4 & 1 & SiL & 5.7 & Anthracnose, Fusarium wilt & No \\
\hline & 5 & 7 & CL & 6.6 & Anthracnose & No \\
\hline & $6-11$ & $1,7,8$ & $\mathrm{~L}, \mathrm{SL}, \mathrm{SiC}, \mathrm{CL}$ & $5.1-6.6$ & $\mathrm{U}$ & No \\
\hline \multirow[t]{2}{*}{ Yamanashi } & 1 & $\mathrm{~N}$ & $\mathrm{~N}$ & 6.6 & $\mathrm{U}$ & P. cactorum \\
\hline & $2-8$ & $\mathrm{~N}$ & $\mathrm{~N}$ & $5.0-7.2$ & $\mathrm{U}$ & No \\
\hline Hokkaido & 1,2 & $\mathrm{~N}$ & $\mathrm{~N}$ & $\mathrm{~N}$ & $\mathrm{U}$ & No \\
\hline
\end{tabular}

a Soil groups included $\mathrm{N}=$ not tested; 1, gray lowland soils; 2, gray lowland soils (fine-textured); 3, yellow soils; 4, gley soils (fine-textured); 5, brown lowland soils; 6, brown forest soils; 7, ando soils; 8, gleyed ando soils; and 9, sand-dune regosols.

${ }^{\text {b }}$ Soil textures included N = not tested;. L, loam; SL, sandy loam; CL, clay loam; LS, loamy sand; SiC, silty clay

${ }^{\mathrm{c}} \mathrm{U}=$ unknown.

plify better at higher salt concentrations which inhibit the denaturation of longer products. In multiplex PCR, adjusting the concentrations of the primer pairs is very important due to the varying copy numbers of the target loci. To obtain similar target signals, the concentrations of different primer pairs were balanced in this research.

Nested PCR is used frequently to improve sensitivity. Meng and Wang (21) applied nested PCR to increase the sensitivity of primers specific for $P$. nicotianae from $1 \mathrm{ng}$ to $10 \mathrm{pg}$. Similarly, Schena et al. (23) were able to raise the sensitivity of primers for 15 Phytophthora spp. from $100 \mathrm{pg}$ to $100 \mathrm{fg}$. We found detection limits for $P$. nicotianae and $P$. cactorum of $100 \mathrm{fg}$ and $1 \mathrm{pg}$ of DNA, respectively, in single as well as multiplex PCR, suggesting very high amplification efficiencies of our primers. Unlike rDNA genes which generally are present in multiple copies, the $Y p t 1$ gene exists as a single copy only (5). This explains why the sensitivity for $P$. nicotianae was always higher than the sensitivity for $P$. cactorum in our tests.

For our investigation into the distribution of $P$. nicotianae and $P$. cactorum in eight strawberry production prefectures of Japan, samples with quite different soil properties were collected. DNA extraction from andosols usually is difficult (25) but our effective extraction method allowed DNA extraction from all soil types. We found that more strawberry production areas were invaded by anthracnose or Fusarium wilt than by Phytophthora spp. in Japan. A few samples had a known Phytophthora rot history but $P$. nicotianae and P. cactorum were detected in some samples independent of their Phytophthora rot history, indicating that several strawberry fields would be potentially infected with Phytophthora spp. The disease caused by $P$. cactorum is often more common in cooler temperatures. However, P. cactorum was found in Saga, a warm region of Japan.

The symptoms of anthracnose and Phytophthora diseases are very similar but fungicides for their control are completely different. Therefore, incorrect diagnoses will cause avoidable problems and financial loss. Although Phytophthora rot has not severely threatened strawberry production in Japan thus far, it is helpful in differentiating Phytophthora disease from anthracnose, which causes serious economic losses in Japan. The technique here introduced proved useful and effective in the discrimination of the pathogens, and will be helpful in the early diagnosis of seedling infection and disease control.

\section{Acknowledgments}

This research was funded by the strawberry project of Japan ("Development of diagnostic program for production of pathogen-free seedlings of strawberry", research and development projects for application in promoting new policy of Agriculture Forestry and Fisheries). We thank M. D. Coffey, S. Uematsu, and H Watanabe for providing isolates of many important Phytophthora spp.; and K. Suzuki, M. Inada, K. Onodera, Y. Hirayama, M. Suzuki, S. Morishima, and M. Sumino for providing soil samples from strawberry planting areas.

\section{Literature Cited}

1. Asano, T., Senda, M., Suga, H., and Kageyama, K. 2010. Development of multiplex PCR to detect vive Pythium species related to turf-grass diseases. J. Phytopathol. 158:609-615.

2. Bhat, R. G., and Browne, G. T. 2010. Specific detection of Phytophthora cactorum in diseased strawberry plants using nested polymerase chain reaction. Plant Pathol. 59:121-129.

3. Blair, J. E., Coffey, M. D., Park, S. Y., Geiser, D. M., and Kang, S. 2008. A multi-locus phylogeny for Phytophthora utilizing markers derived from complete genome sequences Fungal Genet. Biol. 45:266-277.

4. Causin, R., Scopel, C., Grendene, A., and Montecchio, L. 2005. An improved method for the detection of Phytophthora cactorum (LC) Schroeter in infected plant tissues using scar markers. J. Plant Pathol. 87:25-35.

5. Chen, Y., and Roxby, R. 1996. Characterization of a Phytophthora infestans gene involved in the vesicle transport. Gene 181:89-94.

6. Cooke, D. E. L., Drenth, A., Duncan, J. M., Wagels, G., and Brasier, C. M. 2000. A molecular phylogeny of Phytophthora and related oomycetes. Fungal Genet. Biol. 30:17-32.

7. Ersek, T., Schoelz, J. E., and English, J. T. 1994. PCR amplification of species-specific DNA sequences can distinguish among Phytophthora species. Appl. Environ. Microbiol. 60:2616-2621.

8. Goodwin, P. H. Kirkpatrick, B. C., and Duniway, J. M. 1989. Cloned DNA probes for identification of Phytophthora parasitica. Phytopathology 79:716-721.

9. Grote, D., Olmos, A., Kofoet, A., Tuset, J. J., Bertolini, E., and Cambra, M. 
2002. Specific and sensitive detection of Phytophthora nicotianae by simple and nested PCR. Eur. J. Plant Pathol. 108:197-207.

10. Henegariu, O., Heerema, N. A., Dlouhy, S. R., Vance, G.. H., and Vogt, P. H. 1997. Multiplex PCR: critical parameters and step-by-step protocol. BioTechniques 23:504-511.

11. Ippolito, A., Schena, L., and Nigro, F. 2002. Detection of Phytophthora nicotianae and P. citrophthora in citrus roots and soils by nested PCR. Eur. J. Plant Pathol. 108:855-868.

12. Ishikawa, S., Saito, S., Nakayama, K., and Kuniyasu, K. 1990. Phytophthora wilt of strawberry caused by Phytophthora cactorum in Tochigi prefecture. (Abstr.) Ann. Phytopathol. Soc. Jpn. 56:147. (In Japanese)

13. Kageyama, K., Komatsu, T., and Suga, H. 2003. Refined PCR protocol for detection of plant pathogens in soil. J. Gen. Plant Pathol. 69:153-60.

14. Kong, P., Hong, C. X., Jeffers, S. N., and Richardson, P. A. 2003. A speciesspecific polymerase chain reaction assay for rapid detection of Phytophthora nicotianae in irrigation water. Phytopathology 93:822-831.

15. Kong, P., Hong, C. X., and Richardson, P. A. 2003. Rapid detection of Phytophthora cinnamomi using PCR with primers derived from the Lpv putative storage protein genes. Plant Pathol. 52:681-693.

16. Kroon, P. N. M., Bakker, F. T., van den Bosch, G. B. M., Bonants, P. J. M., and Flier, W. G. 2004. Phylogenetic analysis of Phytophthora species based on mitochondrial and nuclear DNA sequences. Fungal Genet. Biol. 41:766782 .

17. Lacourt, I., Bonants, P. J. M., Van Gent-Pelzer, M. P. et al. 1997. The use of nested primers in the polymerase chain reaction for the detection of Phytophthora fragariae and P. cactorum in strawberry. Acta Hortic. 439:82938 .

18. Lacourt, I., and Duncan, J. M. 1997. Specific detection of Phytophthora nicotianae using the polymerase chain reaction and primers based on the DNA sequence of its elicitin gene ParA1. Eur. J. Plant Pathol. 103:73-83.

19. Levesque, C. A., Harlton, C. E., and de Cock, A. W. A. M. 1998. Identification of some oomycetes by reverse dot blot hybridization. Phytopathology $88: 213-222$.
20. Li, M. Z., Senda, M., Komatsu, T., Suga, H., and Kageyama, K. 2010. Development of real-time PCR technique for the estimation of population density of Pythium intermedium in forest soils Microbiol. Res. 165:695705.

21. Meng, J., and Wang, Y. 2010. Rapid detection of Phytophthora nicotianae in infected tobacco tissues and soil samples based on its Ypt1 gene. J Phytopathol. 158:1-7.

22. Schena, L., and Cooke, D. E. L. 2006. Assessing the potential of regions of the nuclear and mitochondrial genome to develop a "molecular tool box" for the detection and characterization of Phytophthora species. J. Microbiol. Methods 67:70-85.

23. Schena, L., Duncan, J. M., and Cooke, D. E. L. 2008. Development and application of a PCR-based "molecular tool box" for the identification of Phytophthora species damaging forests and natural ecosystems. Plant Pathol. 57:64-75.

24. Schena, L., Hughes, K. J. D., and Cooke, D. E. L. 2006. Detection and quantification of Phytophthora ramorum, $P$. kernoviae $P$. citricola and $P$ quercina in symptomatic leaves by multiplex real-time PCR. Mol. Plant Pathol. 7:365-379.

25. Takada-Hoshino, Y., and Matsumoto, N. 2004. An improved DNA extraction method using skim milk from soils that strongly absorb DNA. Microbes Environ. 19:13-19.

26. Takahito, S., Tokio, M., and Akira, O. 1979. Phytophthora rot of Strawberry caused by Phytophthora nicotianae var. parasitica. (Abstr.) Ann. Phytopathol. Soc. Jpn. 45:528. (In Japanese)

27. Takahito, S., Tokio, M., and Akira, O. 1980. Phytophthora rot of Strawberry caused by Phytophthora nicotianae var. parasitica in Shizuoka. Ann. Phytopathol. Soc. Jpn. 46:169-178.

28. White, T. J., Bruns, T., Lee, S., and Taylor, J. 1990. Amplification and direct sequencing of fungal ribosomal RNA genes for phylogenetics. Pages 315 322 in: PCR Protocols: A Guide to Methods and Applications. M. A. Innis, D. H. Gelfand, J. J. Sninsky, and T. J. White, eds. Academic Press, New York 